\title{
ENAM KEKUATAN LAYANAN JASA INTERNET BANKING: TINJAUAN DARI PERSEPSI NASABAH
}

\author{
Ronny \\ STIE Perbanas Surabaya, Surabaya, Indonesia \\ e-mail: dr.ronny@yahoo.com
}

\begin{abstract}
The banking problem studied is the kind of strength which is become the base of services in the field of internet banking. The study was conducted by analyzing the consumers perception in the 5 variables of service quality consist of security, reliability, responsiveness, physical ability, and collateral. As much as 10 informants who are users of internet banking of bank in Indonesia has been interviewed about their perceptions of the quality of internet banking services. This study uses qualitative approach. The analysis showed that there are 6 strength that underlies the quality of internet banking services namely communication, channel of customer participation, service facilities, human resources, technology infrastructure and norms. The sixth strength of the internet banking service is a dimension of strength to compete in the banking industry.
\end{abstract}

Keywords: customer perception, internet banking,service quality

\begin{abstract}
ABSTRAK
Masalah bank yang diteliti adalah kekuatan apa yang menjadi landasan layanan jasa di bidang internet banking. Penelitian dilakukan dengan menganalisis persepsi nasabah pada 5 variabel kualitas layanan yakni keamanan, keandalan, responsif, kemampuan fisik, dan jaminan. Sebanyak 10 informan yang merupakan pengguna internet banking dari bank di Indonesia telah diwawancarai mengenai persepsi mereka terhadap kualitas layanan internet banking. Penelitian ini menggunakan pendekatan kualitatif. Hasil analisis menunjukkan bahwa terdapat 6 kekuatan yang melandasi kualitas layanan jasa internet banking yakni komunikasi, saluran partisipasi nasabah, fasilitas layanan, sumber daya manusia, infrastruktur teknologi dan norma. Keenam kekuatan layanan internet banking tersebut merupakan dimensi kekuatan bersaing dalam industri perbankan.
\end{abstract}

Kata kunci: internet banking, kualitas layanan, persepsi nasabah

Perkembangan Teknologi Informasi memberikan banyak manfaat bagi kehidupan manusia, kemudahan dalam mengolah dan mendistribusikan data, serta berkomunikasi. Berbagai industri menempatkan teknologi informasi sebagai alat bantu yang menghasilkan sumber daya penting dalam perusahaan yakni Informasi. Pemanfaatan Teknologi Informasi dalam industri mengubah fungsi bisnis terutama dalam mendukung pengambilan keputusan yang didasarkan pada informasi yang akurat yang dihasilkan dari teknologi informasi, mendukung efesiensi (Gupta dan Bansal, 2012), 
mampu meningkatkan kinerja, dan mendukung inovasi (Rod et al, 2009; Nimako et al, 2013; Zarei, 2010). Sebagai contoh keberhasilan perusahaan menggunakan teknologi informasi adalah sukses untuk mempromosikan dalam bentuk iklan secara online (Alnsour dan Al-hyari, 2011).

Salah satu industri yang melandasi layanan pelanggan dengan teknologi informasi adalah industri perbankan. Manfaat yang dirasakan perbankan dengan pemanfaatan teknologi informasi adalah penyediaan transaksi online, mampu memperluas hubungan pelanggan dan mempertahankan loyalitas pelanggan. Contoh pemanfaatan teknologi informasi pada industri perbankan seperti ATM, Internet / Telepon / Mobile banking (Punyani et al, 2015).

Bank semakin kuat mengembangkan layanan internet banking karena kemajuan internet dan manfaatnya (Gupta dan Bansal, 2012), serta semakin banyak pengguna internet di dunia. Oleh karenanya, potensi yang bagus bagi perbankan untuk mengembangkan layanan berbasis internet. Kondisi ini menciptakan daya tarik sektor perbankan yang mengundang munculnya pendatang baru (Sohail dan Shaikh, 2008). Akibatnya, persaingan antar bank semakin kompetitif dalam memberikan layanan yang terbaik (Sohail dan Shaikh, 2008), layanan 24 jam setiap harinya, akses yang mudah dan murah dengan berbagai macam jenis transaksi (Al-Ajam dan Nor, 2013). ,

Orientasi layanan dalam dunia bisnis seharusnya mengarah pada orientasi pelanggan. Banyak jasa keuangan lebih fokus kepada nasabah (Safeena et al, 2010), termasuk pemenuhan harapan dan persepsi nasabah agar layanan internet banking terus berubah dengan mengedepankan kualitas layanan (Gupta dan Bansal, 2012). Bank yang tidak dapat melayani nasabah dengan baik mungkin ditinggalkan oleh nasabahnya. Nasabah yang tidak puas dengan proses penanganan masalah internet banking mungkin tidak mengeluh tetapi memilih untuk menggunakan internet banking dari bank lain (Roche, 2014). Oleh karena itu, kualitas layanan menjadi isu penting untuk diperhatikan.

Kualitas layanan telah dilihat sebagai elemen penting dari kepuasan pelanggan (Roche, 2014). Beberapa penelitian kualitas layanan khusus e-banking dan i-banking diantaranya: Nimako et al (2013), Gupta dan Bansal (2012), Zarei (2010), Rod et al (2009) menggunakan variabel privacy, ease of use, realibility, security, responsiveness, effeciency, assuranse, tangible. Penelitian tersebut menekankan pada pengujian dimensi kualitas layanan terhadap adopsi internet banking dan kepuasan nasabah.

Penelitian tentang kualitas layanan internet banking kebanyakan menggunakan analisis data kuantitatif untuk menguji signifikansi pengaruh dimensi kualitas layanan terhadap variabel kepuasan dan adopsi internet banking, masih kurang penelitian yang menggunakan analisis data kualitatif. Posisi penelitian ini menggunakan analisis data kualitatif untuk menganalisis persepsi nasabah mengenai kualitas layanan internet banking. Kontribusi penelitian ini penting dalam pengelolaan internet banking di bank demi meningkatkan layanan dan kepuasan nasabah.

\section{METODE}

Penelitian ini menggunakan pendekatan kualitatif dengan objek penelitian adalah persepsi informan nasabah mengenai aspek penggunaan internet banking yang berkaitan tentang keamanan, keandalan, responsif, kemampuan fisik, dan jaminan layanan. Data dikumpulkan melalui wawancara 10 Informan dari unit analisis nasabah yang menggunakan internet banking bank Mandiri, BCA, Bank Jatim, CIMB Niaga. 
Tabel 1. Karakteristik Informan

\begin{tabular}{cllc}
\hline $\begin{array}{c}\text { Informan } \\
\text { ke- }\end{array}$ & Status & Jenis Kelamin & $\begin{array}{c}\text { Lama penggunaan } \\
\text { Internet Banking }\end{array}$ \\
\hline 1 & Ibu rumah tangga, Pebisnis Online & Wanita & 6 tahun \\
2 & Pegawai swasta & Lak-laki & 5 bulan \\
3 & Pegawai swasta, agen asuransi & Wanita & 4 tahun \\
4 & Dosen & Wanita & 3 tahun \\
5 & Dosen & Lak-laki & 7 tahun \\
6 & Pegawai swasta & Wanita & 2 tahun \\
7 & Pegawai swasta & Lak-laki & 6 tahun \\
8 & Pegawai swasta & Wanita & 3,5 tahun \\
9 & Pengusaha & Lak-laki & 5 tahun \\
10 & Ibu rumah tangga, agen asuransi & Wanita & 6 tahun \\
\hline
\end{tabular}

Pengumpulan data dilakukan dengan menggunakan metode wawancara mendalam untuk mendapatkan deskripsi mengenai kualitas layanan internet banking yang dirasakan informan nasabah. Wawancara menggunakan pertanyaan terbuka yang memungkinkan saat wawacara berlangsung dimunculkan pertanyaan lain untuk memperdalam jawaban informan.

Data yang telah dikumpulkan melalui wawancara kemudian dilakukan reduksi data dengan cara memilih hasil wawancara yang sesuai dengan tujuan pokok penelitian, setelah reduksi data kemudian display data yakni mengelompokkan hasil wawancara berdasarkan variabel yang diteliti, lalu penarikan kesimpulan dengan menggunakan metodologi komparatif konstan (Offstein et al, 2004).

Penarikan kesimpulan sesuai dengan tujuan penelitian ini adalah mendalami persepsi nasabah mengenai kualitas layanan internet banking dan faktor yang mendasarinya. Metodologi komparatif konstan menerapkan logika induktif, intuitif, dan interpretasi. Tujuan komparatif konstan untuk membandingkan dan menemukan hubungan antar kejadian sepanjang penelitian (Offstein et al, 2004).

\section{HASIL DAN PEMBAHASAN}

Penelitian dilakukan pada nasabah sebagai pengguna internet banking bank di Indonesia. Intervensi peneliti terhadap jawaban informan dihindari sehingga diperoleh pendapat yang asli. Sebanyak 10 informan yang diwawancarai mengenai persepsi mereka tentang kualitas layanan internet banking yang digunakan atau diamati selama ini. Rangkuman jawaban informan dikelompokkan menjadi 5 dimensi kualitas layanan, yakni keamanan, kemampuan fisik, responsif, keandalan, dan jaminan.

\section{Keamanan}

Hasil wawancara dengan informan menunjukkan bahwa kekuatiran tentang keamanan disebabkan oleh informan tidak bertatap muka langsung dengan staf bank, tapi hanya melalui teknologi sehingga memerlukan jaminan keamanan bahwa transaksi yang terjadi dapat dicegah dari aksi kejahatan (informan ke-3). Informan ke-10 menerangkan bahwa nasabah membutuhkan keamanan internet banking karena layanan online (internet) pasti bersentuhan dengan teknologi yang memungkinkan pelaku kejahatan melakukan upaya untuk berbuat jahat yang merugikan nasabah seperti mencuri atau memodifikasi data transaksi. Keamanan yang baik dipersepsikan jika 
tidak ada keluhan atau pengaduan terhadap gangguan keamanan yang mengakibatkan kegagalan transaksi (informan ke-8).

Persoalan keamanan yang baik menjadi tantangan prosedur keamanan yang tidak rumit. Informan ke-2 menerangkan bahwa keamanan internet banking terus ditingkatkan, namun jangan sampai penggunaannya menjadi sulit, melainkan sederhana, nyaman dan aman. Aman menurut informan ke-4 jika transaksi dilakukan melalui verifikasi nasabah untuk mengkonfirmasi setiap transaksi yang dilakukan. Verifikasi nasabah menurut informan ke-6 melalui penggunaan perangkat token untuk lakukan transaksi supaya lebih aman terhindar dari serangan hacker yang jahat, nasabah ikut bertanggungjawab menjaga keamanan.

\section{Kemampuan Fisik}

Hasil wawancara mengenai kemampuan fisik, beberapa informan memberikan penjelasan yang singkat mengenai fasilitas layanan dan daya tarik desain website. Dua informan berpendapat bahwa website bank memiliki informasi yang jelas, dapat dipahami dengan mudah (informan ke-3) memiliki tampilan website yang menarik dengan fitur yang sederhana prosedur penggunaannya (informan ke-6).

Fasilitas layanan internet banking dengan fitur yang diharapkan informan adalah fitur internet banking yang sesuai kebutuhan, fiturnya mudah dan aman digunakan (informan ke-7, informan ke-3). Ada fasilitas online messanger agar dapat berkomunikasi dengan staf bank jika ada masalah (informan ke-4). Fasilitas yang dapat diakses dengan cepat, dan terdapat informasi yang menarik perhatian nasabah berupa promosi produk bank (informan ke-9).

\section{Responsif}

Hasil wawancara dengan informan menunjukkan beberapa aspek responsif yang diharapkan dalam layanan internet banking, diantaranya kebutuhan nasabah dapat direspon dengan baik melalui penyediaan fitur website bank (informan ke-1). Respon yang cepat ketika mengakses internet banking, jarang putus (informan ke-2). Bank melakukan sosialisasi dan edukasi nasabah dalam menggunakan internet banking, dan diikuti dengan informasi yang jelas pada website bank (informan ke-4). Jika nasabah menemui masalah dan menghubungi call center, ada kepastian waktu berapa lama sebuah masalah diberikan solusi oleh bank, misalnya masalah gagal transaksi (informan ke-5). Kegiatan menghubungi call center dimudahkan, tidak lama tunggu, tidak lama antri (informan ke-7). Sebagai respon yang baik, nasabah dapat melakukan chat online dengan staf bank yang dapat dihubungi langsung untuk berkomunikasi mengenai kendala dalam menggunakan ibanking (Informan ke-6). Website bank dengan tampilan yang bagus, lebih komunikatif agar dapat dipahami, terdapat konten bantuan yang dapat menolong nasabah (informan ke-10).

\section{Keandalan}

Hasil wawancara dengan informan diperoleh deskripsi tentang faktor keandalan yang diharapkan dalam layanan internet banking, diantaranya layanan bank yang dapat diakses dari beberapa jenis perangkat yang berbeda, apalagi mengingat seorang nasabah mungkin memiliki dan menggunakan beberapa perangkat seperti laptop, komputer, iphone. (Informan ke-1). Dalam kondisi banyak orang menggunakan internet, akses internet banking tetap baik (informan ke-2), akses yang tidak putus (Informan ke-3, informan ke-8, informan ke-10). Layanan bank sesuai dengan standart operational procedure (sop), demikian juga tentang pengamanan, bank sudah menggunakan sop 
pengamanan yang baik dan telah teruji (informan ke-5). Keandalan bank menjadi kepercayaan nasabah karena pasti bank terus meningkatkan layanannya, termasuk keamanan (informan ke-6)

\section{Jaminan}

Hasil wawancara dengan informan menunjukkan Jaminan diantaranya jaminan sumber daya manusia bank yang kualitasnya mampu memberi solusi dan berkomunikasi dengan bahasa yang baik (Informan ke-1). Jika nasabah menghadapi masalah dalam pemakaian internet banking maka staf bank dapat menyampaikan jaminan kepastian waktu berapa lama masalah dapat diselesaikan misalnya masalah gagal transaksi (Informan ke-5). Pelaksanaan prosedur layanan yang mudah dipahami dan terlaksana dengan baik, merupakan jaminan bank atas layanan yang terselenggara (informan ke-9).

\section{PEMBAHASAN}

\section{Kualitas Layanan Internet Banking Keamanan}

Salah satu keunggulan layanan internet banking adalah layanan bank yang dapat dikendalikan sendiri oleh nasabah tanpa perlu berinteraksi langsung dengan staf bank, diistilahkan Online. Ancaman keamanan adalah potensi terjadinya kerugian akibat penipuan atau serangan hacker pada sistem keamanan online (Lee, 2009). Nasri (2011) berpendapat bahwa pelanggan dapat mengelola urusan perbankan mereka, jika mereka menikmati privasi ketika berinteraksi dengan bank.

Keamanan yang dikeluhkan oleh informan ke-2 berkaitan dengan faktor norma yaitu prosedur untuk mengakses internet banking yang dianggap rumit, sehingga prosedur yang sederhana dipandang memberi kemudahan bagi nasabah. Informan ke-4 menekankan pada aspek peran atau partisipasi nasabah dalam ikut mengamankan penggunaan internet banking dengan cara nasabah diberi kesempatan untuk melakukan verifikasi atas setiap transaksi yang akan terjadi. Informan ke-6 menekankan hal yang sama pentingnya partisipasi nasabah dalam pengamanan melalui sistem penggunaan token oleh nasabah atas setiap transaksi yang akan terjadi. Nasabah punya peran penting menjaga keamanan internet banking.

Ada dua alasan sehingga informan merasakan kekuatiran atas sistem online. Pertama, informan tidak terhubung langsung dengan staf bank hanya melalui aplikasi teknologi. Kedua, aksi kejahatan yang dapat mengancam layanan internet banking. Informan tidak paham secara teknis bagaimana bank mengamankan layanan internet banking. Oleh karena itu, derajat keluhan nasabah atas gangguan keamanan yang dialami merupakan indikator penting untuk mengenali seberapa jauh gangguan keamanan dirasakan nasabah.

Sistem keamanan penting melibatkan nasabah dalam konfirmasi transaksi misalnya melalui password dan kode token. Sistem keamanan yang menekankan peran tanggungjawab nasabah untuk turut menjaga keamanan internet banking. Bank seharusnya meningkatkan terus keamanan layanan internet banking, karena aman merupakan manfaat.

Keamanan merupakan faktor penting dalam layanan internet banking yang dapat meningkatkan kepercayaan diri nasabah untuk terus menggunakannya (Lee, 2009). Konsekuensi ini memerlukan pemikiran dan solusi yang tepat bagaimana bank meningkatkan keamanan tetapi tidak menimbulkan peningkatan kompleksitas prosedur penggunaan internet banking yang dapat mengakibatkan lambatnya proses layanan dan berkurangnya kenyamanan nasabah.

Kesimpulan: Keamanan layanan internet banking perlu melibatkan partisipasi nasabah untuk ikut menjaga keamanan dengan norma pengamanan yang sederhana. 


\section{Kemampuan Fisik}

Beberapa informan menekankan pentingnya faktor komunikasi pada website bank: informasi yang jelas (informan ke-3); fasilitas komunikasi seperti online messanger (informan ke-4); desain website yang lebih menarik (informan ke-3); promosi produk (informan ke-9). Informasi yang jelas dan desain website yang menarik akan memudahkan komunikasi dan menarik perhatian nasabah.

Selain faktor komunikasi, informan juga mengarahkan perhatian mengenai faktor infrastruktur teknologi, informan ke-7 dan informan ke-3 mengharapkan tersedia fitur yang aman dan mudah digunakan, sedangkan informan ke-9 menekankan akses website bank yang cepat.

Kemampuan Fisik dalam layanan internet banking merupakan segala kelebihan yang diperoleh nasabah dari website perbankan meliputi fasilitas layanan dan desain website. Fitur layanan penting karena merupakan fasilitas yang disediakan untuk memenuhi kebutuhan nasabah seperti melakukan transaksi melalui fitur transfer uang. Tersedianya fitur layanan yang sesuai kebutuhan nasabah dengan melakukan "update layanan" didukung dengan kemudahan fitur dipelajari dan digunakan, didukung dengan daya tarik desain website dan keberadaan informasi promosi menciptakan kenyamanan nasabah yang memungkinkan nasabah lebih lama untuk berinteraksi dengan website bank.

Kesimpulan: Kemampuan fisik dalam penyelengaraan internet banking seharusnya memperhatikan komunikasi yang baik dan penyediaan infrastruktur teknologi yang aman, mudah digunakan dan akses yang cepat.

\section{Responsif}

Informan menekankan pentingnya responsif pada layanan internet banking didasari pada fasilitas layanan, infrastruktur teknologi, dan komunikasi yang baik. Fasilitas layanan pada website bank maupun di luar website bank, infrastruktur teknologi yang mampu menunjang komunikasi yang mudah dan cepat.

Fasilitas layanan pada website bank dengan berbagai fitur (informan ke-1) yang dapat memenuhi kebutuhan nasabah, di luar website bank tersedia fasilitas layanan call center dengan layanan yang cepat, waktu tunggu yang singkat saat menghubungi call center (informan ke-5 dan informan ke-7), tersedia pula fasilitas layanan chat online (informan ke-6). Sedangkan, infrastruktur teknologi harus mampu mendukung kecepatan akses dan respon komunikasi yang baik pada website bank (informan ke-2).

Komunikasi yang diharapkan informan adalah kemampuan bank melakukan komunikasi melalui sosialisasi dan edukasi nasabah (informan ke-4); website bank yang lebih komunikatif yang mudah dipahami dan terdapat konten bantuan yang dapat menolong nasabah jika mengalami kesulitan menggunakan internet banking (informan ke-10) .

Responsif merupakan persepsi nasabah mengenai kemudahan dan respon yang diperoleh nasabah selama menggunakan internet banking. Pentingnya respon website bank untuk menyediakan fitur yang sesuai kebutuhan nasabah. Jika nasabah merasa rumit atau menemui masalah dalam penggunaan internet banking, maka mereka dapat menghubungi staf bank misalnya melalui call center dengan solusi dan jangka waktu penyelesaian masalah yang jelas. Sosialisasi dan edukasi internet banking pada nasabah merupakan wujud respon bank dalam meningkatkan pemahaman atau pengetahuan nasabah.

Pada kondisi akses internet banking yang cepat maka nasabah merasakan kemudahan menggunakannya, karena konsumen dapat menghemat waktunya (Lee, 2009). Bank merespon kebutuhan nasabah dengan menyediakan fitur yang memadai dalam website bank. Salah satu 
pemenuhan kebutuhan nasabah menurut Lee (2009) adalah nasabah dapat memonitor histori transaksinya.

Aspek bantuan berupa informasi bantuan atau chat online dengan staf bank merupakan harapan nasabah yang berkaitan dengan kecepatan bank merespon dan melayani nasabah. Untuk itu, kualitas komunikasi bank pada nasabah menjadi penting. Menu bantuan yang sederhana dan jelas pada website bank memungkinkan nasabah untuk mudah melakukan transaksi internet banking dan meningkatkan kepuasan nasabah jangka panjang (Waithaka dan Nzeveka, 2015)

Kesimpulan: penyelengaraan internet banking perlu peningkatan fasilitas layanan, infrastruktur teknologi, dan komunikasi.

\section{Keandalan}

Keandalan dalam layanan internet banking terletak pada seberapa jauh infrastruktur teknologi yang tersedia mampu digunakan dan tersedia dalam berbagai keadaan. Informan ke-1 mengharapkan layanan internet banking dapat diakses melalui berbagai jenis perangkat teknologi seperti laptop, komputer, iphone. Dalam keadaan pada jam tertentu banyak orang mengakses internet banking, nasabah tetap dapat mengakses internet banking dalam keadaan baik (informan ke-2), akses yang tidak putus (Informan ke-3, informan ke-8, informan ke-10). Keandalan juga berkaitan dengan norma berupa standart operational procedure (sop) misalnya sop pengamanan yang baik dan telah teruji (informan ke-5).

Keandalan merupakan ketahanan layanan internet banking untuk dapat tersedia dan diakses dengan baik, dapat pulih dari gangguan sehingga tersedia kembali. Pentingnya aksesbilitas website bank tersedia dan mampu diakses dengan baik menggunakan berbagai perangkat teknologi, didukung dengan aturan atau norma yang jelas mengenai prosedur dan tanggungjawab para pihak yang berkepentingan dalam layanan internet banking. Konsisten bank untuk terus memperbaiki dan meningkatkan layanannya merupakan harapan nasabah yang logis untuk meningkatkan keandalan layanan.

Kesimpulan: Keandalan layanan internet banking terletak pada penyelenggaraan internet banking dengan infrastruktur teknologi yang andal dan norma yang baik dan teruji.

\section{Jaminan}

Jaminan dalam penyelenggaraan internet banking bergantung pada 2 faktor yakni sumber daya manusia, dan norma. Sumber daya manusia bank yang diharapkan informan adalah jaminan sumber daya manusia bank yang kualitasnya mampu memberi solusi dan berkomunikasi dengan bahasa yang baik (Informan ke-1), sumber daya manusia bank yang mampu melayani dengan kepastian waktu dalam menyelesaikan masalah nasabah (Informan ke-5). Jaminan layanan internet banking juga didasarkan pada tersedianya norma berupa prosedur layanan yang mudah dipahami dan norma itu mampu menjamin layanan bank (informan ke-9).

Jaminan keamanan menciptakan kepercayaan diri konsumen (Al-Fahim, 2013). Garansi atau jaminan merupakan tuntutan nasabah terhadap layanan internet banking dengan memperhitungkan faktor resiko. Konsumen menekankan adopsi internet banking jika ada jaminan uang kembali sebab mereka tidak menginginkan kehilangan dana akibat hacker (Folake, 2013). Bank dapat meningkatkan kepercayaan nasabah dengan menarik perhatian konsumen, diantaranya memberikan pernyataan jaminan layanan terhadap setiap transaksi sehingga timbul kepercayaan diri konsumen (Lee, 2009). Jaminan layanan internet banking terletak pada kejelasan pada tatakelola internet banking seperti terdapat aturan yang jelas yang diketahui nasabah. Jaminan layanan juga terletak pada 
kualitas sumber daya manusia bank yang seharusnya memiliki pengetahuan dan keterampilan yang memadai tentang layanan internet banking. Bank seharusnya menjamin agar layanan internet banking berjalan dengan aman dan andal, melayani nasabah dengan baik. Kesimpulannya, jaminan layanan internet banking terletak pada faktor kualitas sumber daya manusia dan terdapat norma yang mudah dipahami dan menjamin keberlansungan layanan internet banking.

\section{Kekuatan yang melandasi Layanan Internet Banking}

Dari analisis dan pembahasan lima variabel yang diteliti menunjukkan bahwa kualitas layanan internet banking dari persepsi nasabah terletak pada 6 kekuatan atau fondasi dasar yakni: sumber daya manusia, komunikasi, saluran partisipasi nasabah, infrastruktur teknologi, norma, dan fasilitas layanan.

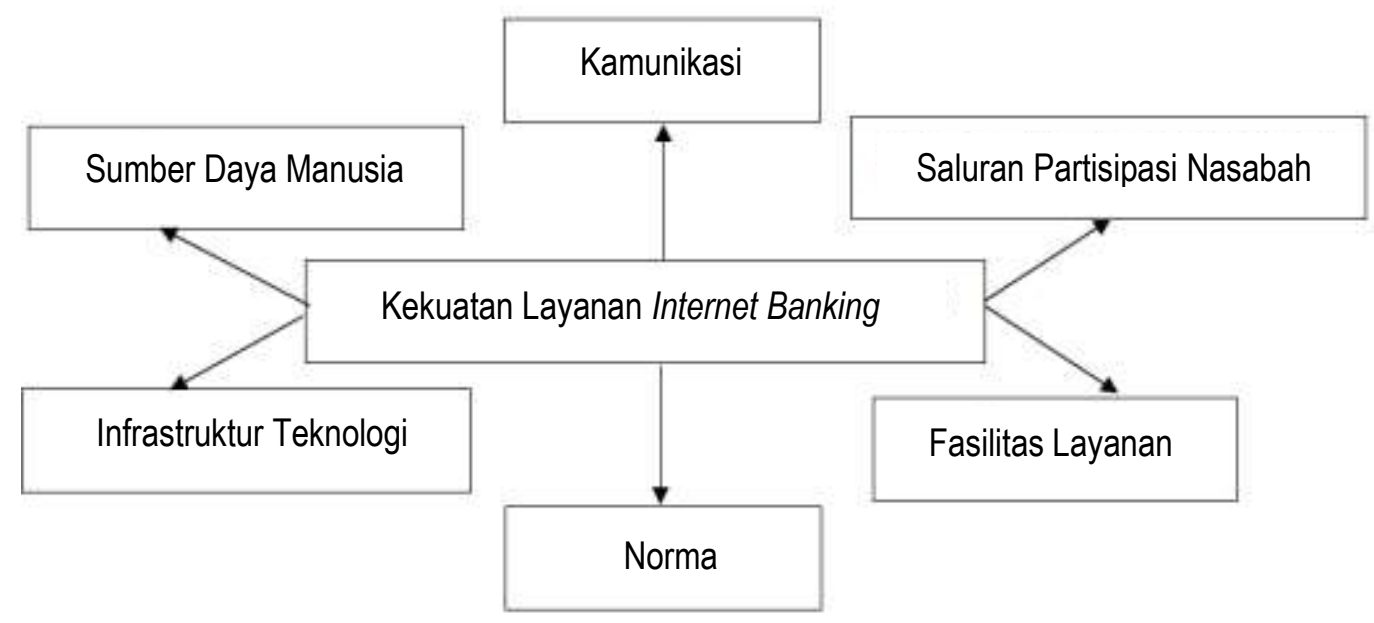

Gambar 1. Kekuatan layanan internet banking

\section{Komunikasi}

Bank mengetahui kebutuhan, kritik, dan pengaduan nasabah melalui interaksi komunikasi yang terjalin dari berbagai jalur komunikasi. Kritik dan pengaduan nasabah merupakan informasi mengenai adanya kekurangan pada layanan, mungkin nasabah membandingkan dengan website bank yang lain dan menemukan kelemahan layanan sehingga kritik dan keluhan nasabah perlu menjadi pertimbangan Bank untuk meningkatkan penyelenggaraan layanan internet banking. Komunikasi merupakan penyampaian dan penerimaan pesan/informasi. Kemampuan komunikasi terdiri atas 3 (tiga) bagian, yakni manfaat informasi, kualitas informasi, dan kualitas interaksi.

Manfaat informasi berkaitan dengan kegunaan informasi dalam website perbankan, seperti informasi yang menjelaskan tentang tujuan fitur, cara menggunakan fitur, informasi promosi, penjelasan keamanan, informasi bantuan, kritik dan saran. Informasi yang bermanfaat harus mampu mengedukasi nasabah. Eze et al (2011) menerangkan bahwa edukasi konsumen merupakan keuntungan konsumen karena mengetahui bagaimana menggunakan internet banking, memproteksi dan mengamankan data privasi.

Kualitas Informasi berkaitan dengan kecepatan, relevansi dan keakuratan informasi dalam merespon permintaan nasabah. Informasi yang cepat diperoleh, relevan dengan kebutuhan nasabah, dan akurat atau terhindar dari kesalahan merupakan informasi yang berkualitas tinggi yang 
mendukung pengambilan keputusan. Sebaliknya, informasi yang berkualitas rendah mengakibatkan pengambilan keputusan menjadi bias. Bank seharusnya meningkatkan terus upaya meningkatkan kualitas informasi karena menentukan kesuksesan internet banking (Namahoot dan Laohavichien, 2015)

Kualitas interaksi adalah kualitas hubungan antara nasabah dengan front line bank, baik melalui call center, customer service, online messanger, juga hubungan antara nasabah dengan website bank. Kualitas interaksi seperti nasabah tidak menunggu lama saat menghubungi call center, staf bank dapat menanggapi keluhan atau pertanyaan pelanggan dengan tepat, respon staf bank yang cepat. Nasri (2011) berpendapat bahwa kenyamanan diperoleh konsumen jika mengeksekusi transaksi bank atau mengontak bank dengan cepat.

\section{Saluran Partisipasi Nasabah}

Saluran partisipasi nasabah penting agar nasabah dapat ikut berperan aktif dalam layanan internet banking, tidak hanya melakukan transaksi. Bank seharusnya memberikan peluang pada nasabah untuk dapat memberikan saran atau kritik, menyediakan sarana dan prasarana yang memungkinkan nasabah turut mengamankan layanan internet banking dengan prosedur yang jelas, serta Bank ikut berperan mengembangkan literasi teknologi nasabah melalui edukasi.

Partisipasi nasabah berupa penyampaian kritik dan saran diperlukan untuk peningkatan kualitas layanan internet banking, mungkin terdapat kritik nasabah yang kurang konstruktif sehingga dapat diabaikan, tetapi saran yang konstruktif menjadi masukan penting untuk perbaikan layanan. Saluran penyampaian kritik dan saran seharusnya bersifat multi channel dengan banyak saluran komunikasi seperti email, sms, telepon, bertemu dengan customer service bank, dan saluran lainnya.

Partisipasi nasabah yang lain adalah nasabah terlibat dalam mengamankan sumber daya internet banking seperti password dan user id, melakukan verifikasi setiap transaksi seperti menerima kode token dan memasukkan kode token ke dalam website bank. Keamanan internet banking tidak hanya menjadi tanggungjawab bank sebagai penyelenggara layanan tetapi juga nasabah ikut bertanggungjawab menjaga kode rahasia yang dimilikinya. Bank harus menyediakan prosedur pengamanan internet banking yang melibatkan peran nasabah dengan mekanisme yang jelas. Bank harus menyediakan saluran komunikasi seperti call center yang dapat digunakan nasabah untuk menyampaikan pengaduan jika ada gangguan keamanan internet banking agar bank segera memberikan bantuan.

Literasi teknologi oleh nasabah diperlukan karena kemampuan penguasaan teknologi informasi, internet, dan internet banking yang rendah dapat berakibat rendahya penggunaan internet banking, sehingga kualitas layanan internet banking memerlukan peranan pengetahuan dan keterampilan nasabah dalam penguasaan teknologi. Pentingnya literasi teknologi ini diterangkan pada beberapa penelitian. Pengetahuan konsumen untuk menguasai penggunaan teknologi informasi seperti internet berpengaruh pada niat menggunakan internet banking (Nasri, 2011). Saeidipour et al (2013) berpendapat bahwa pengalaman konsumen mengenai internet adalah faktor penting konsumen mengadopsi internet banking. Kedalaman pengetahuan merupakan faktor yang memfasilitasi atau membatasi kemampuan nasabah untuk beralih ke layanan bank secara elektronik (Al-Smadi, 2012). Bank seharusnya menyediakan berbagai program edukasi yang mampu untuk meningkatkan literasi teknologi nasabah khususnya kemampuan menggunakan internet banking. Dukungan bank dalam meningkatkan literasi teknologi misalnya melalui penyediaan petunjuk manual penggunaan internet banking, petunjuk pengamanan internet banking dan antisipasi kejahatan. 


\section{Fasilitas Layanan}

Fasilitas layanan internet banking merupakan ujung tombak interaksi nasabah dan bank melalui online atau jalur internet untuk memenuhi kebutuhan nasabah. Internet banking memiliki kualitas yang baik jika mampu mendefinisikan kebutuhan nasabah (Mahfooz et al, 2013). Website bank seharusnya mengandung informasi yang berkualitas tinggi yakni lengkap, mudah diakses, terupdate, akurat, dan aman. Strategi bank dalam layanan internet banking termasuk pengembangan layanan terletak pada keamanan, proteksi informasi personal, jaminan, menurunkan lama tunggu aksesbilitas, semua faktor ini dapat meningkatkan kepercayaan diri nasabah (Al-Smadi, 2012). Fasilitas layanan yang dipersepsikan nasabah mengandung unsur kualitas layanan yakni andal, aman, responsif, kemampuan fisik yang baik, dan adanya jaminan.

Keandalan web menjadi penting, sebab jika internet banking sering mengalami kegagalan transaksi maka penggunaan web perbankan bersifat rumit, menghabiskan waktu, dan menimbulkan ketidakpuasan nasabah. Kemampuan website bank dapat diakses menggunakan berbagai jenis perangkat teknologi informasi dan komunikasi, dapat diakses dalam kondisi bandwidth internet yang rendah merupakan nilai keandalan yang juga dipersepsikan nasabah.

Faktor responsif adalah kemudahan dan respon layanan internet banking sebagai akibat permintaan nasabah. Responsif berkaitan dengan kecepatan akses website bank; kualitas informasi dalam website bank; kesesuaian fitur internet banking dengan kebutuhan nasabah; ragam saluran komunikasi untuk menerima kritik, masukan, dan keluhan nasabah. Responsif juga berkaitan dengan tingkat kemudahan mempelajari dan menggunakan fitur internet banking, semakin mudah menggunakan internet banking akan memberikan kenyamanan pada nasabah.

Faktor keamanan penting dalam internet banking (Nasri, 2011; Perkins dan Annan, 2013). Keamanan dapat dikelompokkan menjadi dua bagian yakni sistem pengamanan dan perlindungan data. Sistem pengamanan adalah web perbankan dapat melayani nasabah dengan fungsi pengamanan yang baik, seperti pengamanan ganda, fasilitas perubahan password, melakukan blokir informasi atau rekening jika terjadi serangan gangguan keamanan. Perlindungan data yakni menjaga kerahasiaan data nasabah yang bersifat privasi, mencegah data error atau data yang tidak akurat.

Kemampuan fisik juga berkaitan dengan jaminan layanan. Fasilitas layanan yang didasari pada aturan diikuti dengan konsistensi pelaksanaannya menjadikan layanan yang terjamin, diikuti dengan prosedur layanan yang tidak rumit, mudah dipelajari, mudah digunakan. Disamping itu, adanya aturan atau norma yang mengatur tentang tanggungjawab masing-masing pihak yakni nasabah dan bank.

\section{Sumber Daya Manusia}

Sumber daya manusia memiliki peran penting dalam layanan internet banking karena kemampuan nasabah menggunakan internet banking dapat berbeda. Aspek sumber daya manusia meliputi kuantitas staf bank, pengetahuan staf bank, dan kecakapan staf bank. Kuantitas staf bank berdampak pada waktu tunggu layanan, misalnya ketika nasabah menghubungi call center maka waktu tunggu antrian menjadi singkat apabila jumlah staf call center mencukupi. Kualitas staf bank yakni pengetahuan dan kecakapan berdampak pada kemampuan staf bank menerima, memproses, dan memberikan solusi atas pengaduan, masukan, dan kritik nasabah atas penggunaan internet banking. 


\section{Infrastruktur Teknologi}

Aspek Infrastruktur Teknologi meliputi aksesbilitas teknologi, ketersediaan fitur, sistem pengamanan, dan perlindungan data: Aksesbilitas teknologi adalah kemampuan teknologi yang mudah digunakan, mudah dipelajari, akses yang cepat, dan fleksibilitas teknologi website bank dapat beroperasi pada berbagai macam perangkat teknologi informasi dan komunikasi; Ketersediaan fitur yang sesuai kebutuhan nasabah dalam melakukan transaksi keuangan; Sistem pengamanan yang baik yang mampu melindungi sistem layanan bank dan perangkat elektronik; Perlindungan data bertujuan melindungi nasabah dari kebocoran dan gangguan data pribadi nasabah. Kegagalan bank dalam melindungi keamanan dan privasi data dapat membuat reputasi bank menjadi buruk (Folake, 2013)

\section{Norma}

Norma merupakan aturan yang diberlakukan dalam layanan jasa internet banking. Norma meliputi Prosedur dan Tanggungjawab yang melibatkan semua proses yang diperlukan atas interaksi nasabah dengan web perbankan dan staf bank yang didukung dengan pemanfaatan teknologi informasi dan komunikasi, seperti prosedur pengamanan, prosedur menerima pengaduan, prosedur registrasi, prosedur reset password. Tanggungjawab merupakan kewajiban yang harus dijalankan dengan baik pihak nasabah maupun pihak bank.

\section{SIMPULAN}

Berdasarkan hasil dan pembahasan dapat diperoleh kesimpulan bahwa terdapat 6 kekuatan atau faktor penting yang melandasi layanan jasa internet banking. Keenam kekuatan tersebut merupakan satu kesatuan yang tidak terpisahkan, yakni komunikasi, saluran partisipasi nasabah, fasilitas layanan, sumber daya manusia, infrastruktur teknologi, dan norma.

Terdapat 21 indikator dari 6 kekuatan yang melandasai jasa internet banking merupakan bahan evaluasi layanan internet banking yakni Kekuatan Komunikasi terdiri 3 indikator yakni manfaat informasi, kualitas informasi, dan kualitas interaksi. Kekuatan Saluran Partisipasi Nasabah meliputi 3 indikator yakni prosedur pengamanan internet banking, edukasi untuk literasi teknologi, saluran komunikasi kritik dan saran. Kekuatan Fasilitas Layanan meliputi 5 indikator yakni aman, andal, responsif, jaminan, kemampuan fisik. Kekuatan Sumber Daya Manusia meliputi 3 indikator yakni kuantitas, pengetahuan, dan kecakapan. Kekuatan Infrastruktur Teknologi meliputi 4 indikator yakni aksesbilitas teknologi, ketersediaan fitur, sistem pengamanan, dan perlindungan data. Kekuatan Norma meliputi 3 indikator yakni prosedur pengamanan, prosedur menerima pengaduan, prosedur penggunaan internet banking.

\section{REFERENSI}

Al-Ajam, A.S. \& K.M. Nor. (2013). Customer's Adoption of Internet Banking Service: An Empirical Examination of the Theory of Planned Behavior in Yemen. International Journal of Business and Commerce, 2(5), 44-58.

Al-Fahim, N.H. (2013). An Exploratory Study of Factors Affecting the Internet Banking Adoption. Global Journal of Management and Business Research, 13(8), 22-32.

Alnsour, M.S., K. Al-hyari. (2011). Internet Banking and Jordanian Corporate Customers: Issues of Security and Trust. Journal of Internet Banking and Commerce, 16(1), 1-14. 
Al-Smadi, M.O. (2012). Factors Affecting Adoption of Electronic Banking: An Analysis of the Perspectives of Banks' Customers. International Journal of Business and Social Science, 3(17), 294-309.

Eze, U.C., L.H. Yaw, \& J. K. Manyeki, L.C. Har. (2011). Factors Affecting Internet Banking Adoption among Young Adults: Evidence from Malaysia. International Conference on Social Science and Humanity IPEDR, 5, 377-381.

Folake, N.P. (2013). The Impact of Trust Antecedents of Internet Banking in Nigeria. International Journal of Economic and Business Management, 2(2), 19-24.

Gupta, K.K. \& I. Bansal. (2012). Development of an instrument to measure internet banking service quality in India. Journal of Arts, Science \& Commerce, 3(2), 11-25.

Lee, M. (2009). Factor Influencing the adoption of internet banking: An Integration of TAM dan TPB with perceived risk and perceived benefit. Electronic Commerce Research and Applications, 8(3), 130-141.

Mahfooz, Y., M. Al-Motairi, \& F. Ahmad, A. Khan. (2013). A Study of the Service Quality Issues of Internet Banking in Non-Metro Cities of India. Journal of Advanced Management Science, 1(1), 75-79.

Namahoot, K.S. \& T. Laohavichien. (2015). Quality Management And Trust Of Internet Banking In Thailand. International Journal of Scientific and Technology Research, 4(9), 257-262

Nasri, W. (2011). Factors Influencing the Adoption of Internet Banking in Tunisia. International Journal of Business and Management, 6(8), 143-160.

Nimako, S.G., N. K. Gyamfi, \& A.M.M. Wandaogou. (2013). Customer Satisfaction With Internet Banking Service Quality In The Ghanaian Banking Industry. International Journal of Scientific \& Technology Research, 2(7), 165-175.

Offstein E.H., M.B Larson, A.L McNeil, \& H.M Mwale. (2004). Are We Doing Enough for Today"s Graduate Students?. The International Journal of Educational Management, 18(7), 396-407.

Perkins, E.D., \& J. Annan. (2013). Factors affecting the Adoption of Online Banking in Ghana: Implications for Bank Managers. International Journal of Business and Social Research (IJBSR), 3(6), 94-108.

Punyani, G., G. Dash, \& S. Sharma. (2015). An Assessment of Customers' e-service Quality Perception Through Webqual Scale: A Study on Online banking Services. International Refereed Research Journal, 6(3), 106-118.

Roche, I.D. (2014). An Empirical Investigation of Internet Banking Service Quality, Corporate Image and the Impact on Customer Satisfaction; With Special Reference to Sri Lankan Banking Sector. Journal of Internet Banking and Commerce, 19(2), 1-18.

Rod, M., N.J. Ashill, J. Shao, \& J. Carruthers. (2009). An examination of the relationship between service quality dimensions, overall internet banking service quality and customer satisfaction. Journal Marketing Intelligence \& Planning, 27(1), 103-126.

Saeidipour, B., H. Ranjbar, \& S. Ranjbar. (2013). Adoption of Internet banking. IOSR Journal of Business and Management (IOSR-JBM), 11(2), 46-51.

Safeena, R., Abdullah, \& H. Date. (2010). Customer Perspectives on E-business Value: Case Study on Internet Banking. Journal of Internet Banking and Commerce, 15(1), 1-13.

Sohail, M.S. \& N.M Shaikh. (2008). Internet banking and quality of service Perspectives from a developing nation in the Middle East. Online Information Review, 32(1), 58-72. 
Waithaka, S.T. \& K.M.J Nzeveka. (2015). Customers Perception on Ease of Use of Internet Banking in Commercial Banks in Kenya. International Journal of Novel Research in Marketing Management and Economics, 2(2), 66-74.

Zarei, S. (2010). Electronic Service Quality Evaluation Methods for Online-Banking System. International Journal of Computer Science and Technology IJCST, 1(2), 6-13. 